LWSA

PAPER - OPEN ACCESS

\title{
Identification of Cultural Heritage Buildings in Langsa City
}

\author{
Author $\quad:$ Bukhari et al. \\ DOI $\quad: 10.32734 /$ lwsa.v3i4.1123 \\ Electronic ISSN $\quad: 2654-7066$ \\ Print ISSN : :2654-7058
}

Volume 3 Issue 4 - 2020 TALENTA Conference Series: Local Wisdom, Social, and Arts (LWSA)

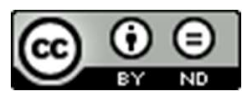

This work is licensed under a Creative Commons Attribution-NoDerivatives 4.0 International License.

Published under licence by TALENTA Publisher, Universitas Sumatera Utara

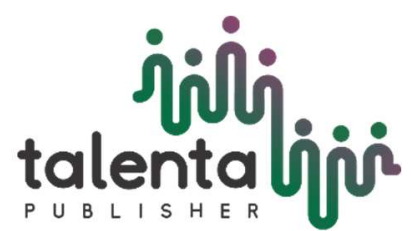




\title{
نं (1) \\ LWSA Conference Series 03 (2020)

\section{Identification of Cultural Heritage Buildings in Langsa City}

\author{
Bukhari, Madhan Anis, Ramazan \\ Universitas Samudra,Jl, Prof. Dr. Syarief Thayeb, Kota Langsa 24354, Indonesia
}

bukhari@unsam.ac.id,madhan.anis@unsam.ac.id,ramazan@unsam.ac.id

\begin{abstract}
Cultural heritage objects are evidence of historical relics/ archaeological inherited from the ancestors which are useful in social life. This heritage needs to be preserved and maintained to increase historical awarenessof the community. Langsa is one of the areas which have a lot of historical heritage. Therefore, the community can be a pioneer in maintaining historical relics, especially those who live around the heritages, so that it will indirectly increase their historical awareness. To achieve that, it is required to trace these historical relics. The purpose of this research is to determine the historical relics identified as cultural heritage in Langsa. The method of this research is the historical method with stages namely the heuristicstage, the source criticismstage, the interpretationstage and historiographystage.
\end{abstract}

Keywords: Identification; Cultural heritage; Langsa.

\section{Introduction}

History is a process of human struggle in achieving a conception of all theirscientifically structured activities by paying attention to the time sequence, given critical interpretation and analysis so that it is easy to comprehend and understand. History can provide conception and actions or human behaviour with all its changes (Susanto, 2014: 7). History leaves its traces which are called historical heritage. Historical heritage becomes an historical inheritancewhich is very valuable asset for nation and if it is properly preserved, it can be used for future generations. According to Ida BagusNyomanWartha (2016: 191), the functions of historical and ancient heritage are; as a medium for nation's cultural education, and a medium to foster nation's personality in the field of culture and national defence. Furthermore in the explanation above, historical heritage is an evidence of historical events that are very useful and play an important role in social life inherited by their ancestors. Therefore, it really needs to be preserved and maintained as a medium to foster nation's personality and national defence.

Cultural heritage objects arean evidence of historical heritage/ archaeological which has great impact in social life which is inherited by ancestors from generation to generation. Therefore, it is very necessary to be preserved and be maintained as a medium to foster historical awareness. One of the areas whichhas a lot of potential historical heritage is Langsa City. Langsa City is an expansion of East Aceh Regency, and Langsa City was previously as an administrative city which then became Langsa City. The juridical basis of forming Langsa City is Law Number 3 of 2001 which was inaugurated on June 21, 2001 (Rachmatsyah, 2014).

Langsa is a small city that has many historical heritage, then Langsa city should be suitable to be promoted as a historical tourism city. Langsa is known for its historical heritage. By the existence of historical heritages in Langsa city should make people aware of their existence, aware information about historical heritages, and understand the benefits of existing historical heritages. With these historical heritages, the society can also play a role as a pioneer to save historical heritage, especially around the area where they live, so that it will indirectly raise historical awareness in society. To achieve that, it is required to identify these historical heritages. So that the problems that will be examined in this research are what historical heritages identified as cultural heritage in Langsa City are. 


\section{Research Method}

In this research, the authors used the stages developed by HeliusSjamsudin namely by using the historical research method which is divided into four stages, namely heuristics, criticism, interpretation, and historiography (Pranoto, 2014). The research stages are:

1. Heuristicsis the stage of collecting historical sources; this is done after the research theme has been chosen. In collecting resources, it must be consistent with the theme that has been chosen. Historical sources themselves are divided into material sources, immaterial or non-material sources, oral sources, first and second sources and source depots (archive / library buildings).

2. Source criticism is a product of scientific process that can be accounted for and in order to avoid fantasy, manipulation or fabrication. Sources must be criticized, verified, or examined for truth and tested for their accuracy. Source criticism itself is divided into two, namely external and internal criticism.

3. Interpretation is the interpretation stage of the collected facts. Interpretation can be carried out by analysis and synthesis.

4. Historiography is the stages of historical writing after all the data or sources have gone through some stages above then they are written innarration.

\section{Results and Discussion}

The focus of this research is to trace historical buildings in Langsa City. This research was conducted from July to August 2020. There are four tracing locations; the first source, namely the section chief of cultural heritage and the section chief of history and traditions under Education Authorities of Langsa City. Second one, Library and Archives Authorities of Langsa City. Third one, Library and Archives Authorities of East Aceh Regency and fourth one is Documentation and Information Centre of Aceh.

From the results of searching the sources, there are several locations of historical heritage buildings which are spread in several locations in Langsa City. They are the Balee Juang building, SD Negeri 1 Langsa, PDAM, Pendopo and Satpol PP Building. Then, Langsa Post Office, Ulee Balang House, PLN office, Asrama Batu, Pegadaian, Tuha Mosque Gampong Teungoh, Rumah Belanda, and various other historical heritage buildings.

Langsa is one of the cities that was built by the Dutch colonial government with the goalto accommodate the interests of foreign capitalism through establishing industrialization of the plantation sector and exploitation of agricultural products. Industrialization is as key factor of many changes in Aceh after the colonial era, especially after the Aceh war (1873-1912). Through industrialization, the Netherlands began to apply the capitalist system as the basis for its new economy. During the Dutch colonial government, Langsa was part ofafdeelingEast Aceh which was called "Afdeeling ooskust van Atjeh". This area was divided into three of Onderafdeeling namely Onderafdeeling Idie, Onderafdeeling Langsa and Onderafdeeling Tamiang. Meanwhile, each Onderafdeeling supervised certain countries. Onderafdeeling Langsa was divided into three countries (landschapper), namely Peureulak, Sunge Raya and Langsa (Sufi, 2008: 132).

Several cities except Kutaraja (now Banda Aceh) became the pillars of the colonial economy from the main industrial sector in the area. For example Kutaraja as the center of trade and government, Peurelak with the petroleum mining industry, Langsa with rubber plantations and Kuala Simpang with petroleum mining and rubber and oil palm plantations. According to Ismail, among those cities only Langsa (onderafdeeling Langsa) and Kuala Simpang (onderafdeeling Tamiang) which emerged as new cities since Industry was present in East Aceh in the first decade of the $20^{\text {th }}$ century, so these findings prove that East Aceh is a very important (Muhajir, 2017: 64).

In a fairly short time, Langsa became a big city which was vital enough for its existence until the end of Dutch colonialism. Various infrastructures were built, so it is not surprising if Langsa then immediately became a colonial city which was filled with typical Dutch style-buildings heritages. This infrastructure was urgently needed to support industrialization, both urban-based and rural-based industries in which both are interrelated.

Industry in urban areas which includes the industries of transportation service, communication services and public services that were built by the colonial government to support industry in rural areas. Industry in rural areas includes the industries of rubber plantation and petroleum mining which are dominated by private capitalists. The rural industry which was developed in Langsa is a type of upstream industry that produces products in the form of semi-finished goods, especially latex and crude oil, which are then sent to downstream industrial areas both domestic and overseas. Industrialization impacts on the growth of Langsa's urban space which indicates society's needs and consumption have been fulfilled by the existence of supporting facilities.

The downtown area, Langsa Tunong, which was built since 1905 has been equipped with important infrastructures such as tram networks, seaports and roads. In addition, the downtown has also been equipped with administrative buildings, city roads, markets and shops, residential areas and factories in a relatively short time. The space for economic activity includes the market shopping area and the availability of financial institutions such as pawnshops, credit banks and state treasury offices. Spaces for social activities include the availability of residential areas for Europeans, Bumiputra and the East Foreign. The availability of land and sea transportation facilities, health facilities, religious and relaxation facilities make more complete for the needs of urban 
residents.

According to Muhajir (2017: 70), the mentioning of Langsa Tunong by colonial government isto mention the new core area of the city, while the original Langsa country is located in an area now called Langsa Lama, and both ware not too far away. Comprehensive urban development planning was initiated in 1905 by the Corps Zeni. Likewise, since 1908, Langsa Tunong was appointed as the capital of Afdeeling East Aceh and Onderafdeeling Langsa with a number of buildings and public facilities that complement it so that in a short time Langsa became a bustling and modern colonial city in the east coast of Aceh.

Colonial traces in Langsa are still clearly figured today. There are still many historical buildings from the colonial era that still stand firm. So that Langsa City becomes one of the cities in Aceh Province which has a lot of high historical value. From most of historical buildings in Langsa city, some of them are used as office buildings owned by Langsa city government. While some have been restored and it becomes worse that some have been dismantled and have lost their historical value.

Since 2016, there have been efforts made by the Langsa city government to maintain the existence of Dutch colonial buildings from extinction. Among the efforts is by establishing five historical buildings as cultural heritage buildings based on the Mayor of Langsa's Decree. The five historical heritage buildings are Balee Juang, SD Negeri 1 Langsa, PDAM, Pendopo and Satpol PP Building of Langsa City.

\subsection{Balee Juang Building}

Langsa museum building, estimated been built in the early $20^{\text {th }}$ century or around the 1910 s. This building is estimated been built for the first time to support the industrial plantation offices which getting better in Aceh region at that time. In 1945 during the war for independence, this building was used by the fighters as one of the buildings where they held meetings to organize resistance against the Japanese and Dutch colonialists. With its function at that time, this building was named Balee Juang. After 1945 this building was functioned by Pupuk Asri company, it was also used by many students' organizations, and in the 1980s this building was officially taken over by the East Aceh Regency Government to become the office of Development Planning Agency at East Aceh. In 2014 the East Aceh Regency Government granted the building for Langsa city government and then the Mayor of Langsa made this building as Langsa Museum Building. This historical heritage building was designated as cultural heritage building based on the decree ofthe Mayor of Langsa Number 188/430/2016 which was set in Langsa on March 7, 2016 by the Mayor of Langsa, Mr. Usman Abdullah.

\subsection{SD Negeri 1 Langsa}

Building of SD Negeri 1 Langsa city is located on Jl. Cut Nyak Dhien, Gampong Jawa, Langsa City District, Langsa City. This building is estimated been built in 1910 with a function as Dutch colonial Military or Military's family Hospital in Langsa. The architecture of the building is in the form of a single elongated building which contains ward rooms that can accommodate an estimated 20 beds. This historical heritage building was designated as a cultural heritage building based on the decision of the Mayor of Langsa Number 189/430/2016 which was established in Langsa on 7 March 2016 by the Mayor of Langsa, Mr. Usman Abdullah.

\subsection{Water Tower of PDAM Tirta Keumueneng}

Tower of PDAM Langsa city was built in 1928 along with clean water facility in Keumueneng. This tower became the center of water channel that was distributed to buildings, offices and settlements during the Dutch colonial era. The architectural feature of the tower is in the form of tower with cast pillar supports that withstand the load of the water reservoir. The water capacity is estimated around 50,000 liters. This historical heritage building was designated as cultural heritage building based on the decree of the Mayor of Langsa Number 190/430/2016 which was set in Langsa on March 7, 2016 by Mayor of Langsa, Mr. Usman Abdullah.

\subsection{Pendopo}

Pendopo building Langsa is estimated to have been built in the early $20^{\text {th }}$ century or around the 1910 s along with the security in Aceh was generally more conducive. This building is the official residence as well as the office building of Dutch officials who govern the government in onderafdelingLangsa which supervises large area including Manyak Payed, Sungai Raya, Peureulak to Lokop and Serbajadi East Aceh. This historical heritage building was designated as a cultural heritage building based on the decree of Mayor of Langsa Number 186/430/2016 which was set in Langsa on March 7, 2016 by Mayor of Langsa, Mr. Usman Abdullah.

\subsection{Building of Satpol PP Langsa}

The Building of Satpol PP \& WH Office in Langsa City is estimated to have been built in the early $20^{\text {th }}$ century or around the 1910s along with the establishment of Langsa museum building. Based on information from local residents, this building was built as office of train in Langsa. This historical heritage building was designated as a cultural heritage building based on the decree of the Mayor of Langsa Number 187/430/2016 which was set in Langsa on 7 March 2016 by the Mayor of Langsa, Mr. Usman Abdullah. 


\section{Conclusion}

Since the beginning of the 20th century, the Dutch colonial government began to take advantage of the East Aceh area. Langsa is one of areas that has succeeded in growing into a modern city from the plantation industry that raised it. Industrial interests in East Aceh are centred in Langsa as the capital city. So it is not surprising that important infrastructure was built in Langsa such as the tram network, sea port and road. In addition, the downtown has also been equipped with administrative buildings, city roads, markets and shops, residential areas and factories in a relatively short time. The space for economic activity includes the market shopping area and also the availability of financial institutions such as pawnshops, credit banks and state treasury offices. Spaces for social activities include the availability of residential areas for Europeans, Bumiputra and the Foreign East. The availability of land and sea transportation facilities, health, religious and relaxation facilities made more complete the needs of urban residents.

Colonial traces in Langsa are still clearly figured today. There are still many historical buildings from the colonial era that still stand firm. They are the Balee Juang building, SD Negeri 1 Langsa, PDAM, Pendopo and Satpol PP Building. Then, Langsa Post Office, Ulee Balang House, PLN office, Asrama Batu, Pegadaian, Tuha Mosque Gampong Teungoh, Rumah Belanda, and various other historical heritage buildings. So that Langsa City becomes one of the cities in Aceh Province which has a lot of high historical value.Since 2016, there have been efforts made by the Langsa city government to maintain the existence of Dutch colonial buildings from extinction. Among the efforts is by establishing five historical buildings as cultural heritage buildings based on the Mayor of Langsa's Decree. The five historical heritage buildings are Balee Juang, SD Negeri 1 Langsa, PDAM, Pendopo and Satpol PP Building of Langsa City.

\section{References}

[1] Muhajir. 2017. IndustrialisasidanEksistensi Kota LangsaPada Era Kolonial, 1907-1942. JurnalParamitha: Historical Studies Journal, Volume 26, No.1.

[2] Pranoto, Suhartono.W. 2010. Teori\&MetodologiSejarah. Yogyakarta: GrahaIlmu.

[3] Rachmatsyah. 2014. MenelaahJejakSejarahLangsa. Langsa.SekretariatdaerahkotaLangsa.

[4] Sufi, Rusdidkk. 2008. SejarahKabupaten Aceh Timur Dari MasaKolonialHinggaKemerdekaan. BadanArsipdanPerpustakaanProvinsiNanggroe Aceh Darussalam.

[5] Susanto, Heri. 2014. SeputarPembelajaranSejarah (Isi, Gagasan, Dan StrategiPembelajaran). Banjarmasin :AswajaPressindo.

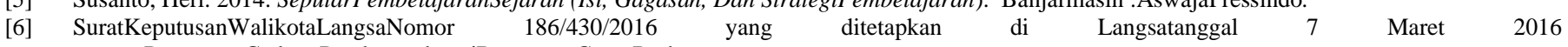
tentangPenetapanGedungPendoposebagaiBangunanCagarBudaya.

[7] SuratKeputusanWalikotaLangsaNomor 187/430/2016 yang ditetapkan di Langsatanggal 7 Maret 2016 tentangPenetapanGedungSatpol PP dan WH sebagaiBangunanCagarBudaya.

[8] SuratKeputusanWalikotaLangsaNomor 188/430/2016 yang ditetapkan di $\quad 2016$ tentangPenetapanGedungBaleeJuangsebagaiBangunanCagarBudaya.

[9] SuratKeputusanWalikotaLangsaNomor 189/430/2016 yang ditetapkan di Langsatanggal 7 Maret 2016 tentangPenetapanGedung SD N 1 Kota LangsasebagaiBangunanCagarBudaya.

[10] SuratKeputusanWalikotaLangsaNomor 190/430/2016 yang ditetapkan di Langsatanggal 7 Maret 2016 tentangPenetapan Tower PDAM TirtaKeumunengsebagaiBangunanCagarBudaya.

[11] Wartha, Ida BagusNyoman. 2016. "ManfaatPenting "Benda CagarBudaya" SebagaiPeninggalanSejarah/ArkeologiUntukKepentingan Agama, SosialBudaya, SosialEkonomi, Pendidikan Dan IlmuPengetahuan (StudiKajianBudaya)”, JurnalSantiagaPendidikan, Volume 6, No 2, Juli 2016. 